\title{
ENTRE OLHARES AO INFINITO E PENSAMENTO MATEMÁTICO: EDUCAÇÃO, VISUAL E PESQUISA ${ }^{1}$
}

\author{
Cássia Aline Schuck ${ }^{2}$ \\ Cláudia Regina Flores ${ }^{3}$
}

\begin{abstract}
Resumo:
Este artigo é um convite para pensar a educação, o visual e a pesquisa com imagens. Partimos de uma perspectiva da visualidade, proveniente da Cultura Visual, para discutir acerca de como afetamos e somos afetados por modos de olhar ao infinito. Para tanto, desenvolvemos uma pesquisa com imagens que sugerem o olhar ao infinito, envolvendo participantes do CAPS-Florianópolis. Foram desenvolvidas quatro oficinas com o objetivo de interagir tanto com modos de olhar ao infinito, quanto com modos de dizer sobre o infinito. Apresentamos aqui alguns fragmentos dessa pesquisa, mostrando a produção de dados e o movimento de cartografar saberes, afetos e olhares. Por fim, salientamos que uma produção de dados entre imagens e visualidades permite problematizar não só o próprio visual, mas as formas de se fazer pesquisa e a própria educação escolar.
\end{abstract}

Palavras-chave: Visualidade; Afeto; Imagem; Educação Matemática; Cartografia

\section{INTRODUÇÃO}

O debate sobre cultura visual é algo amplo, complexo e, às vezes, controverso. Contudo, segundo Knauss (2006, p.102), podemos “considerar duas perspectivas gerais na

\footnotetext{
${ }^{1}$ Esta pesquisa teve o apoio da Capes para a primeira autora, na modalidade de bolsa de mestrado, e do CNPq para a segunda autora, na modalidade produtividade em pesquisa.

${ }_{2}^{2}$ Doutoranda em Educação Científica e Tecnológica pela Universidade Federal de Santa Catarina/UFSC. Professora do Ensino Básico, Técnico e Tecnológico do Instituto Federal Catarinense. Campus Blumenau. Rua Bernardino José de Oliveira, 81 - Bairro Badenfurt, CEP 89.070-270, Blumenau/SC. Endereço eletrônico: cassia.schuck@blumenau.ifc.edu.br.

${ }^{3}$ Doutora em Educação pela Universidade Federal de Santa Catarina/UFSC; Professora no Departamento de Metodologia de Ensino do Centro de Ciências da Educação e do Programa de Pós-Graduação em Educação Científica e Tecnológica da Universidade Federal de Santa Catarina/UFSC. Rodovia Amaro Antônio Vieira, 1788, apt. 802. Itacorubi, CEP 88.034-102. Florianópolis/SC. Endereço eletrônico: claudia.flores@ufsc.br
}

Revista Reflexão e Ação, Santa Cruz do Sul, v. 25, n. 2, p. 215-232, Maio./Ago. 2017.

http://online.unisc.br/seer/index.php/reflex/index 
definição de cultura visual: uma restrita e outra abrangente." Do ponto de vista restrito, a cultura visual estaria relacionada à cultura ocidental, a qual é marcada pela hegemonia do pensamento científico ou pelo domínio da tecnologia - na medida em que ela corresponde aos tempos recentes marcados pela imagem virtual e digital. Já na perspectiva abrangente, considera-se que a cultura visual serve para pensar diferentes experiências visuais ao longo da história, em diversos tempos e sociedades.

Essa última, que atravessa nossa escrita e nossas pesquisas, não toma a visão como algo natural, mas busca questionar a universalidade disseminada da experiência visual. Trata-se de abandonar a centralidade da categoria de visão, como algo apenas físico, e admitir a especificidade cultural da visualidade para caracterizar suas transformações históricas e culturais (JAY, 1996).

No cenário educacional, as imagens têm se tornado tema de pesquisas por estarem cada vez mais presentes no cotidiano das pessoas, criando modos de regulação da vida, modos ver, sentir e pensar o mundo. A escola, por sua vez, desde cedo se constitui num dos principais espaços onde se busca cercar as imagens com significações e objetividades, tomando-as, com frequência, como elemento motivador de ensino. Segundo Hernández, o professor precisa evitar oferecer aos estudantes um espaço carregado de significados preestabelecidos. Para ele, a "subjetividade" deve ser tomada como algo central do projeto da cultura visual, e, assim, se torna relevante a indagação sobre "quem vê", ao invés da tradicional pergunta "o que vemos" (HERNÁNDEZ, 2007). Portanto, trata-se de focar a pesquisa educacional não mais a partir de significações e representações, mas nos discursos que atravessam a formação da vista e que constituem as visualidades.

Imersa nessas discussões da cultura visual, Flores (2007, 2010, 2012, 2013) propõe pensar a constituição do nosso olhar matemático. Afastando-se dos modos tradicionais de se fazer pesquisa em visualização matemática, ela centra a pesquisa no "como olhamos e no como se criaram modos de representar aquilo que olhamos" (FLORES, 2007, p. 27). Disso resultou uma proposição que passou a ser denominada de perspectiva da visualidade para a visualização na educação matemática (FLORES, 2013).

A título de exemplo, esta perspectiva vem sendo operada em pesquisas do GECEM ${ }^{4}$. Entre elas, podemos citar a dissertação de mestrado de Débora Regina Wagner (2012) que realizou um enlace entre arte, técnica do olhar e matemática para colocar em prática um modo perspectivo do olhar, refletindo, assim, sobre a problemática da visualidade no contexto da

\footnotetext{
${ }^{4}$ Grupo de Estudos Contemporâneos e Educação Matemática, diretório CNPq, sediado na Universidade Federal de Santa Catarina, coordenado pela Professora Dra. Cláudia Regina Flores.
}

Revista Reflexão e Ação, Santa Cruz do Sul, v. 25, n. 2, p. 215-232, Maio./Ago. 2017.

http://online.unisc.br/seer/index.php/reflex/index 
Educação Matemática. Para isso, propôs o estudo dos conceitos básicos envolvidos na técnica da perspectiva a partir do Tratado de Pintura de Alberti $^{5}$, publicado em 1435, compreendendo os enunciados que formavam uma trama discursiva daquela época.

Outro exemplo é a tese de Ivone Buratto (2012) que refletiu sobre o papel da historicidade e da visualidade para a formulação de uma outra narrativa na Educação Matemática. Seu objetivo foi discutir e analisar de que modo uma narrativa centrada na imagem poderia proporcionar uma compreensão do visual como construção cultural e histórica. A partir do artesão renascentista Albrecht Dürer, ela problematizou as elaborações teóricas e a condição da época na constituição de um modo de ver, relacionando exercício com e para a educação matemática na atualidade.

A dissertação de Liliane Medeiros (2014), também integrante do GECEM, teve como objetivo identificar quais eram os discursos predominantes que emergiam da visualidade de licenciandos, de um curso de Matemática da UFSC, quando se deparavam com imagens em anamorfose. Para isso, cartografou um grupo de cinco participantes e constatou que, para esse grupo, o discurso visual que prevalecia era aquele ligado à racionalidade, objetividade e transparência no que se vê.

Também, a dissertação de João Moraes (2014) se estabeleceu por uma cartografia com alunos de uma sala de quinto ano do Ensino Fundamental do Colégio de Aplicação da UFSC. $\mathrm{O}$ trabalho procurou problematizar como estes alunos experimentam saberes matemáticos a partir de pinturas do artista Kandinsky, especificamente as relações do saber matemático na representação do corpo.

Ainda, Cássia Aline Schuck (2015), em sua dissertação de mestrado, cartografou como um grupo de participantes do CAPS $^{6}$, Florianópolis, reage ao olhar imagens que sugerem uma visão ao infinito ${ }^{7}$, isto é, como afetam e são afetados por modos de olhar ao infinito. Deste trabalho, em particular para este artigo, apresentamos como se deu a produção de dados e o movimento de cartografar saberes, afetos e olhares ao infinito. No seu enredo, este artigo se elabora de modo a lançar um convite para repensar a educação matemática, o visual, e a pesquisa com imagens.

\section{UM PERCURSO DE DESASSOSSEGOS - CULTURA VISUAL E VISUALIDADE}

\footnotetext{
${ }^{5} \mathrm{O}$ Tratado de Pintura, escrito por Alberti é a primeira aplicação racional e coerente de uma teoria relacionada à arte e à pintura, apresentando os fundamentos da prática, baseada na geometria de Euclides e na ótica geométrica.

${ }^{6}$ Centro de Atenção Psicossocial.

${ }^{7}$ Esta pesquisa teve a autorização da Secretaria Municipal de Saúde de Florianópolis e cumpre com a Resolução CNS 466/2012, com aprovação no CEPSH/UFSC.

Revista Reflexão e Ação, Santa Cruz do Sul, v. 25, n. 2, p. 215-232, Maio./Ago. 2017. http://online.unisc.br/seer/index.php/reflex/index
} 
Relacionar matemática e arte com o objetivo de tornar o ensino de matemática mais significativo, mais prazeroso e contextualizado é uma das propostas que ainda se lê nos Parâmetros Curriculares Nacionais (BRASIL, 1998). A fim de notar como as pesquisas estavam tratando esse aspecto, Flores e Wagner (2014) realizaram um mapeamento de teses e dissertações, defendidas entre 1987 e 2013, que abordam arte e educação matemática. As autoras notaram que pesquisadores têm ampliado, cada vez mais, esse espaço de pesquisa, disseminando ideias sobre possíveis relações entre matemática e arte, e inferindo proposições para o ensino e aprendizagem da matemática. A aposta é que através da arte, e mais amplamente de imagens, seja possível proporcionar um ensino contextualizado de conceitos matemáticos, bem como desenvolver habilidades visuais.

Entretanto, a perspectiva da visualidade para a visualização na Educação Matemática (FLORES, 2010, 2012, 2013) vem propondo o uso do termo visualidade nas pesquisas em Educação Matemática, deslocando-se do foco na semiótica, na psicologia cognitiva, na percepção visual, e propondo a análise de visualidades. Trata-se de uma estratégia para entender as relações do sujeito e das experiências visuais com tecnologias visuais, o que significa "acentuar cultura visual e visualidade como estratégia teórica e metodológica e como uma dimensão importante que abrange práticas do olhar na constituição de formas e experiências do olhar em matemática" (FLORES 2010, p. 291).

O conceito de visualidade, proveniente da cultura visual, "é entendido como a soma dos discursos que informam como nós vemos" (FLORES, 2013, p. 93-94). Por meio dele busca-se "fornecer uma base para a análise de práticas visuais, explorando o papel de conceitos matemáticos em regimes visuais" (FLORES, 2013, p. 94), problematizar formas naturalizadas de olhar, representar e ensinar na matemática, e propor exercícios de pensar matemática por meio de imagens (FLORES, 2016).

Disto tudo, consideramos que a pesquisa com arte, imagens e educação matemática, pode tomar outras direções que, muitas vezes, nos aparecem obscuras e perturbadoras, colocando-nos sob uma trajetória que não dá sossego, que é conflitante, pois não há regra, objetivo a alcançar, problema para responder. Por isso, a intenção deste artigo é iluminar um desses trajetos, mostrando seu percurso, sua produção e possíveis resultados, mas, sobretudo, a possibilidade e a materialidade de se fazer pesquisa por tal viés.

\section{CARTOGRAFAR NA DIFERENÇA - DA OBJETIVIDADE PARA A SUBJETIVIDADE}

Revista Reflexão e Ação, Santa Cruz do Sul, v. 25, n. 2, p. 215-232, Maio./Ago. 2017.

http://online.unisc.br/seer/index.php/reflex/index 
A cartografia se coloca como outra forma de pesquisar, em que:

Não precisamos mais temer o processo de estarmos sendo afetados pelo acontecimento no ato de pesquisar, pois o que antes era dado como "ponto fraco" do pesquisador, agora marca uma condição indispensável do processo de pesquisar: a capacidade de afetar e afetar-se para que se criem os modos de expressar os sentidos de uma pesquisa. (LAZZAROTO; CARVALHO, 2012, p. 27).

Proposto por Deleuze e Guattari (1995), o termo cartografia se elabora a partir do interesse pelo estudo da subjetividade ${ }^{8}$, mais especificamente, "como modo de acompanhar processos de produção de subjetividade" (BARROS; KASTRUP, 2012, p. 90). De acordo com Suely Rolnik (2007, p. 66), o cartógrafo se define por um tipo de sensibilidade: "entender, para o cartógrafo, não tem nada a ver com explicar e muito menos com revelar. Para ele não há nada em cima — céus de transcendência —, nem embaixo — brumas da essência. O que há em cima, embaixo e por todos os lados são intensidades buscando expressão."

Imersas nessa proposição, no lugar de buscar respostas para questões pré-estabelecidas, de conformar metodologias, ou de encontrar resultados generalizantes, um exercício de cartografar na diferença foi realizado por Cássia Schuck (2015). No caso, o modo de produção de dados e o método de intervenção precisaram ser inventivo para potencializar afetos, subjetividades, mas também pensar sobre infinito e matemática. Foram criadas quatro intervenções com imagens, as quais se tornaram platôs dentro da pesquisa como um todo ${ }^{9}$. As intervenções foram desenvolvidas com participantes do CAPS, e ocorreram entre 24 de setembro a 14 de outubro de 2014 e, em cada encontro centrou-se no propósito sobre "como afetamos e somos afetados por modos de olhar ao infinito" (SCHUCK, 2015). Nomeadamente, essas oficinas-intervenções foram chamadas de Quebrando a cabeça, afetando olhares; Um olho, compondo infinitos olhares; Olhares no Arco-íris; Saindo da Casinha. Todos os momentos foram gravados, filmados e transcritos.

Na primeira delas, como proposta de experimentar, ou seja, "ultrapassar o que se coloca como limite entre o sujeito e o objeto" (LAZZAROTTO, 2012, p.101), foram utilizadas sete

\footnotetext{
${ }^{8}$ Segundo Mansano (2009, p. 111), Deleuze e Guatarri compreendem subjetividade "como um processo de produção no qual comparecem e participam múltiplos componentes. Esses componentes são resultantes da apreensão parcial que o humano realiza, permanentemente, de uma heterogeneidade de elementos presentes no contexto social. Nesse sentido, valores, ideias e sentidos ganham um registro singular, tornando-se matéria prima para expressão dos afetos vividos nesses encontros. Essa produção de subjetividades, da qual o sujeito é um efeito provisório, mantém-se em aberto uma vez que cada um, ao mesmo tempo em que acolhe os componentes de subjetivação em circulação, também os emite, fazendo dessas trocas uma construção coletiva viva".

${ }^{9}$ A pesquisa na íntegra pode ser acessada em: http://www.gecem.ufsc.br/.
}

Revista Reflexão e Ação, Santa Cruz do Sul, v. 25, n. 2, p. 215-232, Maio./Ago. 2017.

http://online.unisc.br/seer/index.php/reflex/index 
imagens do artista Escher ${ }^{10}$, a saber: Limite circular III; Queda de água; Limite quadrado; Cada vez mais pequeno I; Desenhar; Borboletas; e Répteis. Estas imagens foram ampliadas, impressas em papel apropriado e recortadas em forma de quebra-cabeças (Fig. 1). Com elas, a ideia era que os participantes pudessem manipulá-las, senti-las, pensar não só como encaixar as peças para obter a imagem como um todo, mas para provocar e dar espaço para um momento de experiência.

Fig. 1 - Fragmentos

Fonte: arquivo pessoal.

Em um olho, compondo infinitos olhares, performatizamos o espaço do ateliê de artes do CAPS com uma trama de monóculos suspensos no ar (Fig. 2). Em cada monóculo uma imagem. Estas imagens eram de diferentes artistas, mas todas sugeriam um pensamento voltado para a ideia de infinito. Os participantes foram convidados a circular pela trama, manipular os monóculos e, enfim, escolher a imagem que mais lhe afetou, aquela que insiste, que força a olhar para ela, que agencia memórias, que agencia vida, que agencia modos de olhar. A partir daí, com esta imagem eles deveriam expressar seus pensamentos com desenhos, escritas ou dobraduras, cores e formas. Vale destacar, aqui, que o verbo "expressar" é tomado com um sentido que difere da expressão, mas com o sentido de "inventar" (MAURENTE, 2012, p.109).

\footnotetext{
${ }^{10}$ Maurits Cornelis Escher $(1898$ - 1972) foi um artista gráfico holandês que ficou conhecido pelas suas xilogravuras, litografias e meio-tons, que intencionam representar construções impossíveis, preenchimento regular do plano, explorações do infinito e metamorfoses.

Revista Reflexão e Ação, Santa Cruz do Sul, v. 25, n. 2, p. 215-232, Maio./Ago. 2017.

http://online.unisc.br/seer/index.php/reflex/index
} 
Olhares no arco-íris foi o nome dado para uma outra instalação, agora labiríntica (Fig. 3), composta por imagens que foram afixadas em tecido TNT e penduradas na parede de uma sala. Pelo labirinto os participantes puderam circular, observar, conversar, desenhar e produzir olhares e dizeres, registrando-os em pequenos papéis coloridos que comporiam um grande painel de pensamentos e movimentos do grupo.

Fig. 3 - Entre pelo outro lado!

Fonte: arquivo pessoal.

Por fim, como uma proposta de sair da "casinha", ou seja, do espaço propriamente do CAPS, os momentos anteriores e as diferentes produções dos participantes foram penduradas ao ar livre (Fig. 4). Circulando por estas imagens, os participantes, assim como o próprio pesquisador, puderam re-elaborar, re-pensar, re-inventar cenas e diálogos que levaram a pensar sobre infinito. 


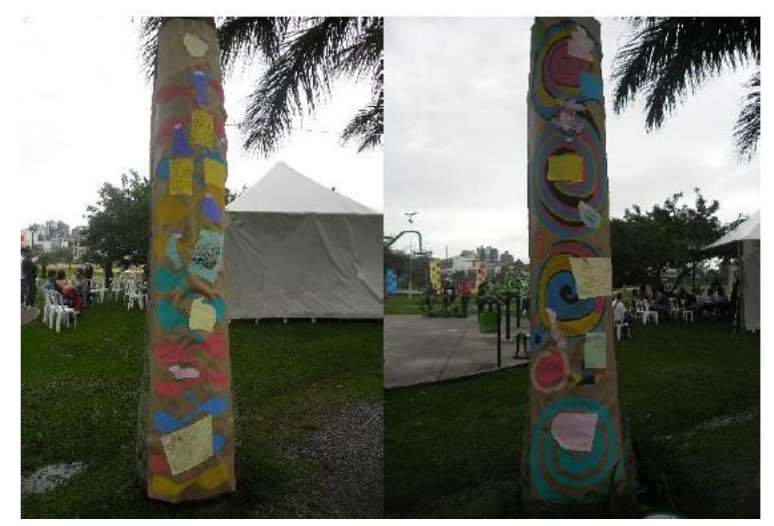

Fig. 4 - Composição de afetos

Fonte: arquivo pessoal.

Com esses momentos de oficina/intervenção procurou-se acompanhar o processo em que o objetivo foi justamente cartografar um território que, em princípio, não se habitava, não se tinha ideia do que fazia, do que era. "O que se significa que não era um pesquisar e deslocar por um espaço conhecido, mas de produzir conhecimento ao longo de um percurso de pesquisa." (KASTRUP, 2012, p. 45). Foi preciso, portanto, despir-se do sabido, liberar-se de amarras, largar o método para viver o momento, respirar o ar, parar e ouvir. Foi deste movimento que uma dissertação, um texto, um mapa, uma cartografia puderam ser produzidas. De tudo o que ficou em registro, cabe-nos aqui apresentar um fragmento, uma parte, ou melhor, compor uma nova cartografia a partir de uma ponta desta pesquisa.

\section{FRAGMENTOS DO QUEBRANDO A CABECA}

Era um dia chuvoso. Inicialmente, eles - os participantes do CAPS presentes naquele $\mathrm{dia}^{11}$ - espalharam as peças do quebra-cabeça e buscaram ver a imagem que dele se compunha. Um convite foi lançado: vamos montar quebra-cabeça? Os olhares (Fig. 5 e Fig. 6) eram atenciosos para as peças, mesmo quando a conversa era sobre algum aspecto da vida particular, ou da luta para liberar-se de vícios. As peças iam e vinham num movimento ágil para uns, paciente para outros. Além do conhecido som da chuva vindo lá de fora, ouvia-se a música que vinha da caixa de som e que invadia o silêncio, penetrava as falas, confundia o ouvido, mistura as imagens.

\footnotetext{
${ }^{11} \mathrm{O}$ ateliê de artes do CAPS-Florianópolis é um lugar onde sempre encontramos alguém novo e deixamos de ver alguém conhecido.
}

Revista Reflexão e Ação, Santa Cruz do Sul, v. 25, n. 2, p. 215-232, Maio./Ago. 2017.

http://online.unisc.br/seer/index.php/reflex/index 


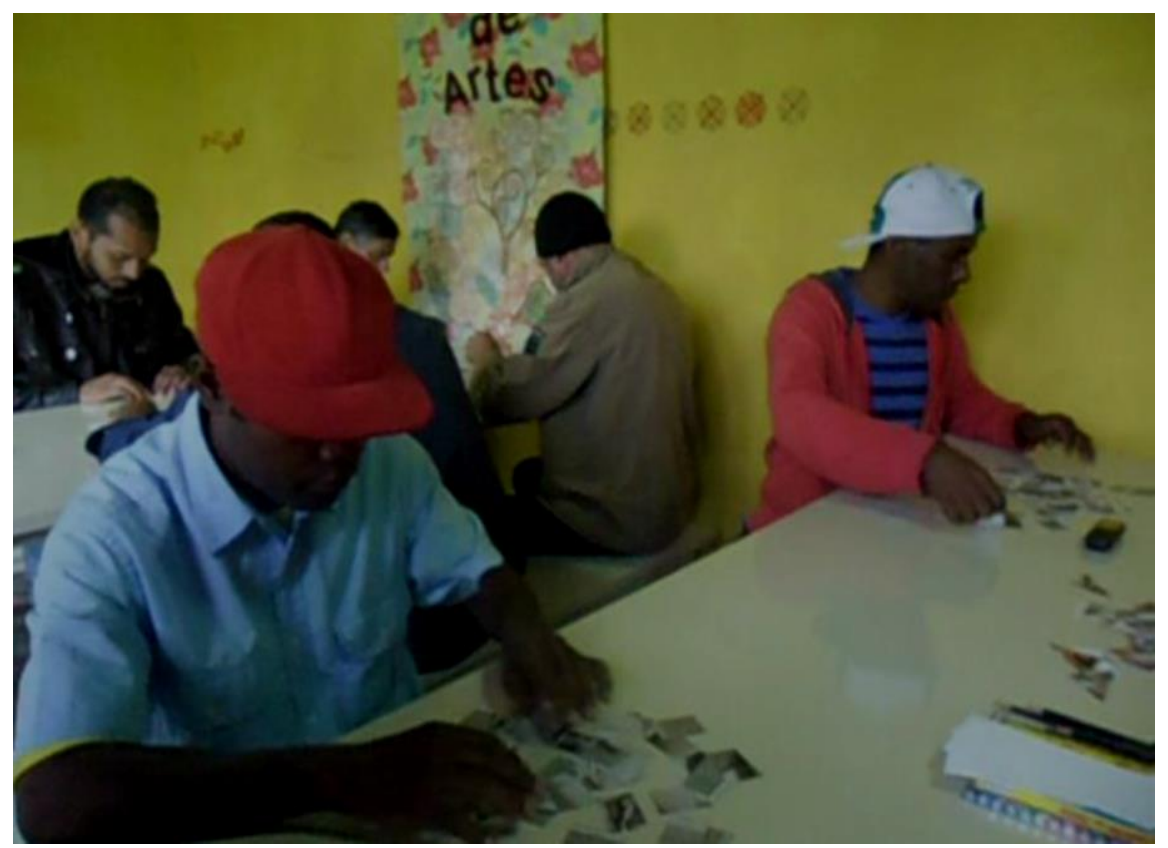

Fig. 5 - Quebrando a cabeça.

Fonte: arquivo pessoal.

Além do conhecido som da chuva vindo lá de fora, o som da música que vinha da caixa de som invadia o silêncio, penetrava nas falas, confundia o ouvido.

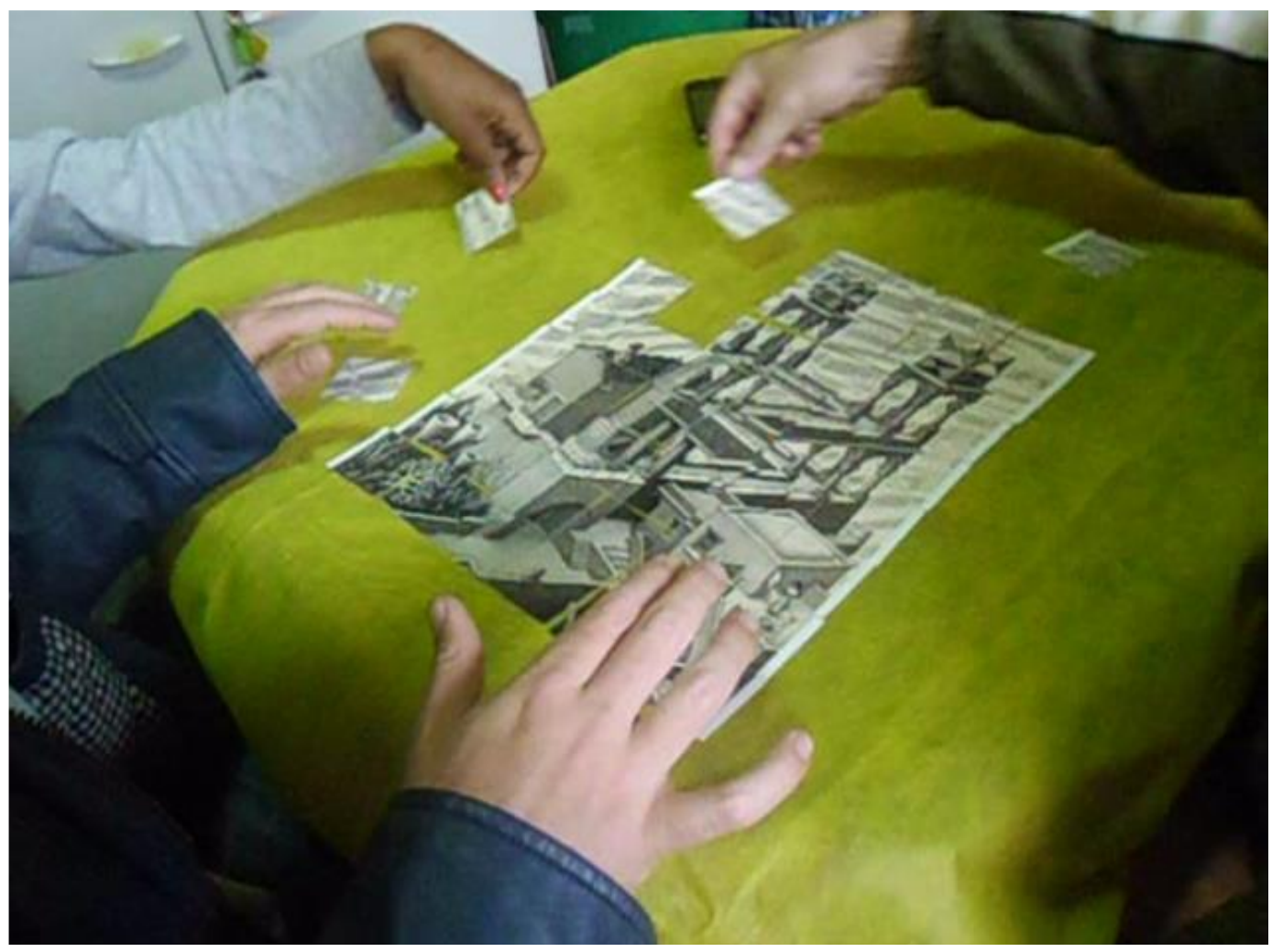

Fig. 6 - A loucura de Queda d'água.

Fonte: arquivo pessoal.

Revista Reflexão e Ação, Santa Cruz do Sul, v. 25, n. 2, p. 215-232, Maio./Ago. 2017.

http://online.unisc.br/seer/index.php/reflex/index 


\section{E aí, como que foi?}

Legal!

E o que mais impactou, assim, na imagem?

Descobrimo ela. No começo não dava pra entender o que essas coisas aqui tinham a ver com o castelo. Não entendia o que isso tinha a ver com o castelo, pareciam que eram desenhos diferentes. Parece que eles tão tudo isolado.

Mas montando, um foi interagindo com o outro e foi montando uma imagem só. Porque no início pareciam desenhos totalmente aleatórios entre si.

\section{$E$ vocês repararam no castelo?}

Sim. Parece que ele é isolado, não tem nada.

Eu reparei que ele é um castelo muito louco na verdade.

É, bem doido.

Por quê? Qual é a loucura desse castelo?

Meio psicodélico.

A loucura do castelo começa por esses lances aqui, essas imagens geométricas ali em cima e parece que ele, ao mesmo tempo que ele é meio medieval, ele usa uma tecnologia de abastecimento de água, que também gera energia pra ele mesmo, o moinho ali.

Essa água tá subindo ou tá descendo para mover o moinho?

Tá fazendo os dois.

Os dois? E como a água pode fazer as duas coisas?

Eu não consegui entender também. Como que ela chega lá em cima? Sei lá.

Por isso que o castelo é louco! Por isso é louco! (risos).

Porque o moinho joga água pra cá e devolve pro próprio moinho. $A$ força do moinho alimenta ele mesmo.

$E$ esse movimento termina?

Não, é cíclico, né! E ele não é um castelo, na verdade, ele faz parte de uma vila eu acho. Aqui tem uma casa, aqui tem outra. Lá atrás tem uma plantação.

O fragmento compõe o mapa, os pedaços, a imagem. Aqui, em particular, destacamos o que nos salta e que podemos chamar de "práticas de pensar matematicamente" (FLORES, 2015), que pode ser entendido como um pensamento regido pela tirania da racionalidade. Ao propor que o movimento é cíclico (Fig. 6), associamos, nós também, que os participantes expressam um olhar ao infinito que, por sua vez, é atravessado por um dado discurso da matemática. Mas, também eles, os participantes, fazem da matemática algo "complexo" ao eleger os elementos geométricos como culpados de uma certa "loucura" na imagem. Surge 
aqui efeitos de superfície, ou efeitos dos discursos que os constituíram, e constituem, enquanto sujeitos - um modo de olhar, de pensar, de analisar.

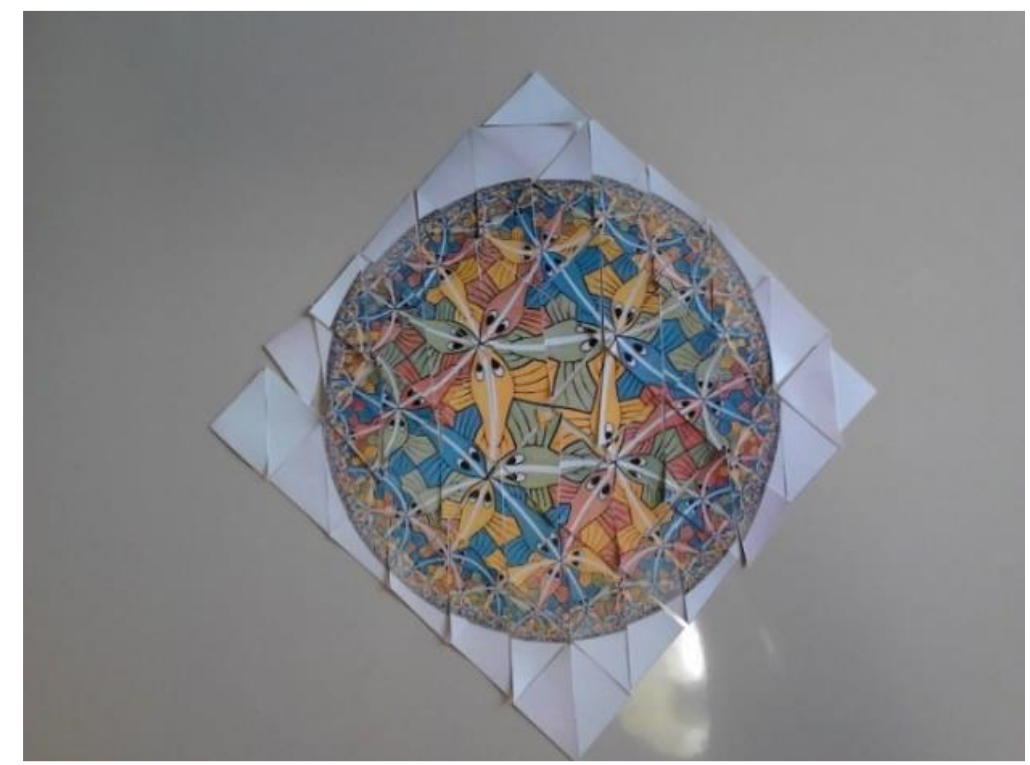

Fig. 7 - Fome.

Fonte: arquivo pessoal.

Isso aqui tá parecendo o fundo de um mar, sei lá... isso aqui parece peixe pra mim, não sei... um monte de peixe... pode ser um monte de peixe dentro de um aquário...

Tá mais pra uma rede, né?

Por que pra uma rede?

Ah, porque tão muito junto, né.

Vocês acham que eles estão todos juntinhos?

Tão. Se não tão, parecem.

Mas nem tudo é pensar a matemática. Eles viram os peixes, grandes e pequenos, e sentiram a parte do mar morrendo, a baia, tiveram fome e lembraram do gosto de peixe e de camarão. Eles pensaram com a imagem e buscaram objetivar efeitos de subjetividade.

Nessa mesma ocasião, e passado algum tempo, foi entregue a cada grupo de participantes um pequeno pedaço de papel com algumas informações sobre Escher.

Isso aí a gente não consegue compreender (apontando para a frase "explorações do infinito" que indicava uma fase do artista). Por quê? 
Porque isso aí é coisa de Deus, uma coisa divina preencher o infinito.

Por quê? (insisto)

Porque Deus é perfeito, a gente só falha.

(...)

O que é o infinito pra ti?

$O$ mar. E pra você o que é o infinito?

O céu.

\section{Por quê?}

O céu não tem dor.

Ei, você está escondendo as peças? Está contra nós? (risos)

É que eu também quero montar um pouquinho.

$E$ essa imagem fez pensar algo sobre o infinito?

Eu penso! Penso que nossa baía tá falecendo, porque se tu olhar em volta tão acabando com o pescador artesanal

E você?

Eu sou meio tímido!

... então dá de ver que tem uma questão política aí, eles criam as indústria que tomam conta do espaço.

Salta-nos, portanto, o fato sobre como cada um deles, e cada um de nós, valoriza aquilo que afeta no momento e que faz parte de uma vida, colocando-se nos sentidos do dizer e do ver, um modo visual de olhar para as coisas, e particularmente, um modo de olhar ao infinito. Ora, "as experiências vão então ocorrendo, muitas vezes fragmentadas e sem sentido imediato" (KASTRUP, 2012, p. 39), constituindo o sujeito que vê, as visualidades possíveis, e os modos como nos educamos. De acordo com Berger (1999, p. 10), "a maneira como vemos as coisas é afetada pelo que sabemos ou pelo que acreditamos", ou seja, nossas experiências formam nossos modos de ver.

Aqui, portanto, vimos alguns pedaços que dialogam com maneiras de olhar ao infinito, que são atravessadas pelas experiências dos participantes, afinal,

A vida, enquanto campo de forças, pode ser referida como uma sucessão de acontecimentos - de produções cujos efeitos, por sua vez, corporificam-se ampliando o produzir para as mais diversas formas de relações, afetos, desejos, ideias, expectativas, subjetividades enfim, historicamente datadas. (SCHEINVAR, 2012, p. 195).

\section{EM MEIO ÀS VISUALIDADES}

Com tal pesquisa, a pretensão não foi criar categorias, ou blocos de concepções para explicar sobre o olhar. Mas, sim, dar vez e voz aos afetos que pedem passagem no tempo e no Revista Reflexão e Ação, Santa Cruz do Sul, v. 25, n. 2, p. 215-232, Maio./Ago. 2017.

http://online.unisc.br/seer/index.php/reflex/index 
espaço das intervenções. Afetos cujos modos de olhar afetaram aquelas imagens e que também foram afetados por elas. São efeitos daquilo que foi vivido, aprendido, às vezes imposto como verdade, às vezes pura emoção. Afinal, quando nos referimos à visualidade, ao modo como olhamos para alguma coisa, consideramos um olhar construído em meio aos discursos visuais, e que não possuem nada de essencial, antes é resultado de algo que foi prática discursiva. Portanto, não queremos representar uma suposta realidade deste grupo de participantes sobre os olhares ao infinito, mas nos deixar-se atravessar por processos de invenção, de afetos, de visualidades, e poder pensar práticas para a educação matemática.

Nos encontros realizados foram potencializados muitos e distintos efeitos que reverberam em diferentes enunciados que dizem dos olhares ao infinito. Entre os participantes do CAPS surgiu um ideal de infinito que não é necessariamente conceito matemático, como o ponto de fuga da perspectiva central, ou a ideia de continuidade em conjuntos numéricos, ou as mónodas da reta, ou os limites no Cálculo Diferencial. Mas pensamentos fecundados por um olhar ao infinito que é ligado à salvação de Deus, à busca por um dia após outro dia, aos degraus de uma escada, ou horizonte promissor.

Para Foucault (2012, p. 39), os enunciados, mesmo que "diferentes em sua forma, dispersos no tempo, formam um conjunto quando se referem a um único e mesmo objeto.” Em particular, aqui, falamos de um conjunto de enunciados que forma nossos discursos sobre os olhares ao infinito. As falas que constituem essa pesquisa não são, necessariamente, os próprios enunciados, como talvez possamos pensar, mas elas dizem a respeito deles, e por isso, os problematizamos. Afinal, "a unidade do discurso é feita pelo espaço onde diversos objetos se perfilam e continuamente se transformam, e não pela permanência e singularidade de um objeto" (FOUCAULT, 2012, p. 40).

Assim, só temos este ou aquele olhar ao infinito porque houve um jogo de regras que os tornou possíveis. Os enunciados, incluindo aqueles relacionados ao olhar ao infinito, pertencem a uma mesma formação discursiva e constituem-se em "coisas que se transmitem e se conservam, que têm um valor, e das quais procuramos nos apropriar; que repetimos e reproduzimos e transformamos" (FOUCAULT, 2012, p. 147).

Eis, portanto, um convite: pensar o visual, a educação e a pesquisa. Pensar a pesquisa em Educação Matemática pela Arte, com arte. “Os modos de ser, os desejos, as sensações, as expectativas entendidas como subjetividades historicamente constituídas são produções, muitas vezes apenas perceptíveis em sua singularidade. Entender as práticas é rastrear a historicidade na qual foram produzidas.” (SCHEINVAR, 2012, p. 196). 
No entre, no entremeio, por entre a arte e a matemática, um outro modo de educar, que é por um viés que há sempre espaço para falar com e entre pessoas, falar com e entre imagens, falar da matemática, falar de matemática, que é vida, falar da vida. É falar daquilo que nos forma, ou deforma, daquilo que é comum e que é feito pela sua própria historicidade.

\title{
BETWEEN LOOKS TO INFINITY AND MATHEMATICAL THINKING: EDUCATION, VISUAL AND RESEARCH
}

\begin{abstract}
This article is an invitation to think the education, the visual as well as the research with images. We start from a perspective of visuality, from the Visual Culture, to discuss about how we affect and are affected by ways of looking at the infinity. To this end, we have developed a research with images that suggests the look to infinity, involving CAPSFlorianópolis participants. Four workshops were developed with the aim of interacting with both ways of looking and ways to say about infinity. We present here some fragments of this research, showing the producing of data and the effort of mapping knowledge, affects and looks. Finally, we point out that a production of data between images and visualities allows not only discussing the visual itself, but also the ways of doing research and the education itself.
\end{abstract}

Keywords: Visuality; Affectio;. Image; Mathematics Education; Cartography

\section{ENTRE MIRADAS AL INFINITO Y PENSAMIENTO MATEMÁTICO: EDUCACIÓN, INVESTIGACIÓN Y VISUAL}

\footnotetext{
Resumen

Este artículo es una invitación a pensar la educación, la visual, así como la investigación con imágenes. Partimos desde la perspectiva de la visualidad, de la cultura visual, para discutir acerca de cómo nos afectan y son afectados por formas de mirar el infinito. Con este fin, hemos desarrollado la investigación con imágenes Que sugiere la mirada al infinito, con participantes CAPS- Florianópolis. Cuatro talleres fueron desarrollados con el objetivo de Revista Reflexão e Ação, Santa Cruz do Sul, v. 25, n. 2, p. 215-232, Maio./Ago. 2017. http://online.unisc.br/seer/index.php/reflex/index
} 
interactuar con las formas de ver y maneras de decir sobre el infinito. Presentamos aquí algunos fragmentos de esta investigación, que muestra el productor de los datos y el esfuerzo de los conocimientos de cartografía, afecta y se ve . Por último, señalamos que la producción de datos entre imágenes y visualidades no sólo permite discutir la propia visual, sino también las formas de hacer la investigación y la propia educación.

Palabras clave: La visualidade; Afecto; Imagen; Educación Matematica; Cartografía

\section{REFERÊNCIAS}

BARROS, Laura. Movimento sensível e vital: uma oficina articulando a cegueira com o mundo. Rio de Janeiro: UFRJ, 2013.

BARROS, L.; KASTRUP, V. Cartografar é acompanhar processos. In: PASSOS, E.; KASTRUP, V.; ESCÓSSIA, L. da. (Org.). Pistas do método da cartografia: pesquisaintervenção e produção de subjetividade. Porto Alegre: Sulina, 2012.

BELLO, Samuel. Jogos de linguagem, práticas discursivas e produção de verdade: contribuições para a educação (matemática) contemporânea. Revista Zetetiké, São Paulo, Unicamp, v. 18, 2010. Número temático.

BERGER, John. Modos de ver. Rio de Janeiro: Rocco, 1999.

BRASIL, Secretaria de Educação Fundamental. Parâmetros Curriculares Nacionais: Arte. Secretaria de Educação Fundamental. Brasília, DF: MEC/SEF, 1998.

BURATTO, Ivone. Historicidade e visualidade: proposta para uma nova narrativa na Educação Matemática. 2012. Tese de Doutorado (Programa de Pós-Graduação em Educação Científica e Tecnológica) - Universidade Federal de Santa Catarina, Florianópolis.

COSTA, L.; ANGELI, A.; FONSECA, T. Cartografar. In: FONSECA, T.; NASCIMENTO, M.; MARASCHIN, C. (Org.). Pesquisar na diferença: um abecedário. Porto Alegre: Sulina, 2012.

DELEUZE, G.; GUATTARI, F. Mil platôs. v.1. Rio de Janeiro: Ed. 34, 1995.

FLORES, Cláudia R. Olhar, saber e representar: sobre a representação em perspectiva. São Paulo: Editora Musa, 2007.

Cultura visual, visualidade, visualização matemática: balanço provisório, propostas cautelares. Revista Zetetiké, São Paulo, Unicamp, v. 18, p. 277-300, 2010.

. Visuality and mathematical visualization: seeking new frontiers. In: 12th

International Congress on Mathematical Education. 8 July - 15 July, Seoul, Korea, 2012.

Revista Reflexão e Ação, Santa Cruz do Sul, v. 25, n. 2, p. 215-232, Maio./Ago. 2017.

http://online.unisc.br/seer/index.php/reflex/index 
Visualidade e Visualização Matemática: Novas Fronteiras para a Educação

Matemática. In: FLORES, C. R.; CASSIANI, S. (Org.). Tendências contemporâneas nas pesquisas em educação matemática e científica: sobre linguagens e práticas culturais. Campinas: Mercado de Letras, 2013. prelo, 2016.

Descaminhos: potencialidades da arte com a educação matemática. Bolema: No

FLORES, C. R; WAGNER, D. R. Um mapa e um inventário da pesquisa brasileira sobre Arte e Educação Matemática. In: Educação matemática pesquisa-PUCSP, abril, 2014.

FOUCAULT, Michel. Arqueologia do saber. Rio de Janeiro: Forense Universitária, 2012.

HERNÁNDEZ, Fernando. Catadores de cultura visual: transformando fragmentos em nova narrativa educacional. Tradução de Ana Duarte. Porto Alegre: Mediação, 2007.

JAY, Martin. Introdution: vision in context: reflections and refractions. In: BRENNAN, T.; JAY, M. (Ed.). Vision in context: historical and contemporary perspectives on sight. New York, London: Routledge, 1996.

KASTRUP, Virgínia. O funcionamento da atenção no trabalho do cartógrafo. In: PASSOS, E.; KASTRUP, V.; ESCÓSSIA, L. da (Org.). Pistas do método da cartografia: pesquisaintervenção e produção de subjetividade. Porto Alegre: Sulina, 2012.

KNAUSS, P. O desafio de fazer História com imagens: arte e cultura visual. ArtCultura, Uberlândia, v. 8, n. 12, p. 97-115, jan./jun. 2006.

LAZZAROTTO, Gislei. Experimentar. In: FONSECA, T.; NASCIMENTO, M.; MARASCHIN, C. (Org.). Pesquisar na diferença: um abecedário. Porto Alegre: Sulina, 2012.

LOBO, Lilia. Pesquisar: a genealogia de Michel Foucault. In: FONSECA, T.;

NASCIMENTO, M.; MARASCHIN, C. (Org.). Pesquisar na diferença: um abecedário. Porto Alegre: Sulina, 2012.

MANSANO, Sonia. Sujeito, subjetividade e modos de subjetivação na contemporaneidade. Revista de Psicologia da UNESP, v. 8, n. 2, 2009.

MAURENTE, Vanessa. Expressar. In: FONSECA, T.; NASCIMENTO, M.; MARASCHIN, C. (Org.). Pesquisar na diferença: um abecedário. Porto Alegre: Sulina, 2012.

MEDEIROS, Liliane. Anamorfoses em formação: tensionando hábitos e discursos de futuros professores de matemática. 2014. Dissertação de Mestrado (Programa de Pós-Graduação em Educação Científica e Tecnológica) - Universidade Federal de Santa Catarina, Florianópolis.

PASSOS, E.; EIRADO, A. Cartografia como dissolução do ponto de vista do observador. In: PASSOS, E.; KASTRUP, V.; ESCÓSSIA, L. da (Org.). Pistas do método da cartografia: pesquisa-intervenção e produção de subjetividade. Porto Alegre: Sulina, 2012. 
PASSOS, E.; KASTRUP, V.; ESCÓSSIA, L. da (Org.). Pistas do método da cartografia: pesquisa-intervenção e produção de subjetividade. Porto Alegre: Sulina, 2012.

ROLNIK, S. Cartografia sentimental. Porto Alegre: Sulina, 2007.

SCHEINVAR, Estela. Produzir. In: FONSECA, T.; NASCIMENTO, M.; MARASCHIN, C. (Org.). Pesquisar na diferença: um abecedário. Porto Alegre: Sulina, 2012.

SCHUCK, C. A. Cartografar na diferença: entre imagens, olhares ao infinito e pensamento matemático. 2015. Dissertação (Mestrado em Educação Científica e Tecnológica) Universidade Federal de Santa Catarina, Florianópolis.

VEIGA-NETO, Alfredo. Foucault \& a educação. 3 ed. Belo Horizonte: Autêntica Editora, 2011. 